\title{
Exploring the Perceived Feedback of Commercial Dairy Farmers about Effectiveness of Android Mobile Apps 'Brucellosis Advisor Apps'
}

\author{
A.P. Verma ${ }^{1 *}$, H.R. Meena ${ }^{2}$, K.S. Kadian ${ }^{2}$ and B.S. Meena ${ }^{2}$ \\ ${ }^{1}$ Krishi Vigyan Kendra, Bharari, Jhansi-283001, India \\ ${ }^{2}$ Dairy Extension Division, ICAR-National Dairy Research Institute, \\ Karnal, 132001, Haryana, India \\ *Corresponding author
}

\begin{tabular}{|l|}
\hline Ke y w o r d s \\
Brucellosis, Mobile \\
$\begin{array}{l}\text { Application, Perceived } \\
\text { feedback, Prevention, } \\
\text { Dairy animals }\end{array}$ \\
\hline Article Info \\
\hline $\begin{array}{l}\text { Accepted: } \\
\text { 20 December } 2018 \\
\text { Available Online: } \\
\text { 10 January } 2019\end{array}$ \\
\hline
\end{tabular}

\section{A B S T R A C T}

A myriad of mobile technologies purport to help individuals change or maintain healthrelated behaviours, for instance by increasing self-awareness or motivation. To disseminate the information regarding Brucellosis prevention in dairy animals a mobile application called "Brucellosis Advisor App" was developed. This paper is devoted to explore the perceived feedback of commercial dairy farmers of Haryana and Punjab state on effectiveness of android mobile application. To measure the perceived feedback of respondents a list of items seeking responses on different aspects of mobile application were prepared and administered to the respondents. Each respondent was asked to response on a three-point continuum: highly satisfied, satisfied and least satisfied with the statements, with a score of 3,2 and 1, respectively. Based on the scores the perceived feedback of commercial dairy farmers was calculated using weighted mean score. It was found that the respondents were highly satisfied in the following aspects of Brucellosis Advisory App components: Meet the needs of target group, Applicability of Mobile application in field condition, Layout of Mobile application is good, Accuracy and appropriateness of the health information on Mobile application, Simplicity of content in enhancing knowledge and was ranked first among the each of the five component listed respectively.

\section{Introduction}

Information asymmetry acts as one of the major restraints on the growth of agriculture and allied sectors in India. One of the most emphatic ways to address this situation is by encouraging the adoption of Information and Communication Technologies (ICTs) by researchers as well as extension professional to transmit relevant information to dairy farmers (Salau and Saingbe, 2008). Several researchers backed this finding in different parts of the world, which entrenched many possible applications of ICT in agricultural extension and rural development specifically in accessing required information, knowledge and technology required in farming (Ajayi et al., 2013). Among innovative ICT tools, mobile phones served as most effective means for transfer of animal health information to dairy farmers that enable them to adopt the specific measures to their farm which in turn 
improves their dairy farming output and make easy access to veterinary services. The use of mobile apps for health and well-being promotion has grown exponentially in recent years (Riley et al., 2011). Global use of smart phones increasing day by day and Internet usage via mobile devices has increased manifold. The portability of smart phones provides access to health information and interventions at any time in any context. The capabilities of smart phones can also enhance the delivery of these health resources (Stoyanov et al., 2018). So, considering the above fact Mobile app was thought to be the best means to disseminate information on brucellosis prevention among commercial dairy farmers.

Mobile application was operationalized as "the act or process by which application software is developed for mobile devices which delivered as mobile application using server-side or client-side processing to provide an "application-like" experience for a mobile user. Through mobile apps subject matter content (Prevention of Brucellosis) through text and images transferred to the commercial dairy farmers. It helps to educate the user about a technology and can be stored and operated from any type of android smart phone. This study tries to reveal the perceived feedback of the respondents about different components of the developed android application called "Brucellosis Advisor Apps". Respondents in this case are the commercial dairy farmers of Haryana and Punjab state. Perception is the process, by which one can be able to see, hear and understand things from surrounding environments.

Hence, it is assumed that greater the perception of Mobile application as perceived by its viewers/users in terms of satisfaction derived from the various components of application, greater would be the viewers' exposure and post exposure activities.

\section{Materials and Methods}

\section{Locale of study and sampling plan}

The study was conducted in Haryana and Punjab state. Each state comprises 22 districts. Out of them, six districts (3 from each state) were selected based on highest cattle population. Among these selected districts, 20commercial dairy farmers were selected from each district based on snowball sampling method. Pooling which made a total of 120 respondents that were interviewed to get primary information on brucellosis with the help of well-structured interview schedule. Out of which only sixty respondents were randomly chosen, ten from each selected district to explore the perceived feedback of the commercial dairy farmers.

\section{Statistics Used in the Study}

The degree of effectiveness of the developed android mobile appson brucellosis can be assessed through respondents' perceived feedback. In this paper simple questionnaire method was followed to measure perceived feedback on effectiveness of android mobile app on brucellosis. It is anticipated that better the perception by the commercial dairy farmers in terms of satisfaction derived from the various components of mobile Apps greater is its effectiveness. On the basis of satisfaction, the respondents were categorised into three groups viz., highly satisfied, satisfied and least satisfied. Then frequency, percentage, weighted mean score and rank was calculated for each component and each statements.

\section{Results and Discussion}

For measuring the perceived feedback of the respondents about the developed android mobile application; five categories were made Engagement Component, Functionality Component of the apps, Aesthetic Component, 
Information Component and Subjective Component of the apps. Result and Discussion of all component is described below:

Respondents' perceived feedback on effectiveness about different component of Mobile Application (Apps)

Results about the apps component and its satisfaction level, it was observed from the (Table 1) that respondents were highly satisfied in the following aspects of apps components: 'Engagement' was ranked first in the satisfaction continuum, this could be due to the fact that mobile application has selfguiding features, which made the usage of the application easy among the respondents, and 'Functionality' was ranked second, this could be because every individual have the tendency to get attracted things which have applicability in field condition. Information Function was ranked third; this is due to the fact that respondents found it sufficient and reliable information on brucellosis. While 'aesthetic value' and 'subjective quality' were ranked fourth and fifth in this regard respectively. The probable reasons for this could be because respondents had different preference on layout, color scheme, text size etc. Later this problem was solved by incorporating and modifying the designing of the mobile application. Similar results were also reported by Shrija et al., (2018) that respondents were highly satisfied in the following aspects of apps components: user-friendliness, relevance of the content, attractiveness of the photos/graphics and was ranked first among the each of the three categories listed respectively.

\section{Respondents' perceived feedback on effectiveness about the Engagement Component of the Apps}

The result about engagement component and its satisfaction level, it was found that (Table 2) majority of the respondents were satisfied with all characteristic of engagement component of mobile application. Meet the need of target group was given first rank, because respondents found that it is directly related to their problems and create interest among users was ranked second, this could be because every individual have the tendency to get attracted towards new technology. While mobile application provide links to other credible sites/servers and Mobile number/Email ID is easy to register in Mobile application were ranked third and fourth in this regard respectively. The probable reasons for this could be because respondents had varying degree of exposure to these institute and low technical knowledge.

\section{Respondents' perceived feedback on effectiveness about the Functionality Component of the Apps}

Results regarding functionality component and its satisfaction level, it was found (Table 3) that respondents were satisfied in following components: Applicability of Mobile application in field condition was given first rank, the probable reasons behind this could be the problem of brucellosis which respondents perceived in dairy animals.

Mobile application contains headings and subheadings which helps the user in finding information was given second rank while degree of easiness in obtaining desired information in simplest way was given third rank in this regard respectively. The probable reason may be that application has selfguiding and simplified features, which made the usage of the application easy among the commercial dairy farmers. Findings of the present study supported by Monica et al., (2011) who also observed overall appropriateness of developed e-module on photography in terms of mean scores was highest for modular applicability, presentation of e-module and multimedia presentation and interactivity, respectively. 
Table.1 Respondents' perceived feedback on effectiveness about different component of Android Mobile Apps "Brucellosis Advisor Apps" ( $\mathrm{n}=60)$

\begin{tabular}{|c|l|c|c|c|c|c|}
\hline Sl. No. & \multicolumn{1}{|c|}{$\begin{array}{c}\text { Component of } \\
\text { application }\end{array}$} & $\begin{array}{c}\text { Highly } \\
\text { Satisfied }\end{array}$ & Satisfied & $\begin{array}{c}\text { Least } \\
\text { Satisfied }\end{array}$ & $\begin{array}{c}\text { Weighted Mean } \\
\text { Score }(\%)\end{array}$ & Rank \\
\hline 1. & Engagement & $43(71.67)$ & $17(28.33)$ & $0(0.00)$ & 90.56 & I \\
\hline 2. & Functionality & $42(70.00)$ & $14(23.33)$ & $4(6.67)$ & 87.78 & II \\
\hline 3. & Aesthetic Value & $32(53.34)$ & $26(43.33)$ & $2(3.33)$ & 83.33 & IV \\
\hline 4. & Information Function & $39(65.00)$ & $18(30.00)$ & $3(5.00)$ & 86.67 & III \\
\hline 5. & Subjective Quality & $22(36.67)$ & $32(53.33)$ & $6(10.00)$ & 75.56 & V \\
\hline
\end{tabular}

Table.2 Respondents' perceived feedback on effectiveness about the Android Mobile Apps "Brucellosis Advisor Apps" (Engagement Component) $(n=60)$

\begin{tabular}{|c|l|c|c|c|c|c|c|}
\hline S1. No. & \multicolumn{1}{|c|}{ Mobile Application } & $\begin{array}{c}\text { Highly } \\
\text { Satisfied }\end{array}$ & Satisfied & $\begin{array}{c}\text { Least } \\
\text { Satisfied }\end{array}$ & $\begin{array}{c}\text { WMS } \\
(\%)\end{array}$ & Rank \\
\hline A & ENGAGEMENT & $24(40.00)$ & $32(53.33)$ & $4(6.67)$ & 77.78 & II \\
\hline 1. & \begin{tabular}{l} 
Create interest among users \\
\hline 2.
\end{tabular} & $\begin{array}{l}\text { Meet the needs of target group } \\
\text { Mobile application provide }\end{array}$ & $18(30.33)$ & $32(53.33)$ & $2(3.33)$ & 80.00 & I \\
\hline 3. & $\begin{array}{l}\text { Mon } \\
\text { links to other credible } \\
\text { sites/servers }\end{array}$ & $36(60.00)$ & $6(10.00)$ & 72.52 & III \\
\hline 4. & $\begin{array}{l}\text { Mobile number/Email ID is } \\
\text { easy to register in Mobile } \\
\text { application }\end{array}$ & & & & & \\
\hline
\end{tabular}

(*Figures in parentheses indicate percentage)

Table.3 Respondents' perceived feedback on effectiveness about the Android Mobile Apps "Brucellosis Advisor Apps" (Functionality Component) (n=60)

\begin{tabular}{|c|l|c|c|c|c|c|c|}
\hline S1. No. & \multicolumn{1}{|c|}{ Characteristics } & $\begin{array}{c}\text { Highly } \\
\text { Satisfied }\end{array}$ & Satisfied & $\begin{array}{c}\text { Least } \\
\text { Satisfied }\end{array}$ & $\begin{array}{c}\text { WMS } \\
(\%)\end{array}$ & Rank \\
\hline B & \begin{tabular}{l} 
FUNCTIONALITY \\
\hline 1.
\end{tabular} & $\begin{array}{l}\text { Applicability of Mobile } \\
\text { application in field condition }\end{array}$ & $40(66.67)$ & $17(28.33)$ & $3(5.00)$ & 87.22 & I \\
\hline 2. & $\begin{array}{l}\text { Degree of easiness in obtaining } \\
\text { desired information in simplest } \\
\text { way }\end{array}$ & $20(33.33)$ & $36(60.00)$ & $4(6.67)$ & 75.56 & III \\
\hline 3. & $\begin{array}{l}\text { Mobile application contains } \\
\text { headings and subheadings which } \\
\text { helps the user in finding } \\
\text { information }\end{array}$ & $23(38.34)$ & $35(58.33)$ & $2(3.33)$ & 78.33 & II \\
\hline
\end{tabular}

(*Figures in parentheses indicate percentage) 
Table.4 Respondents' perceived feedback on effectiveness about the Android Mobile Apps "Brucellosis Advisor Apps" (Aesthetic Component) ( $\mathrm{n}=60)$

\begin{tabular}{|c|l|c|c|c|c|c|c|}
\hline S1. No. & \multicolumn{1}{|c|}{ Characteristics } & $\begin{array}{c}\text { Highly } \\
\text { Satisfied }\end{array}$ & Satisfied & $\begin{array}{c}\text { Least } \\
\text { Satisfied }\end{array}$ & $\begin{array}{c}\text { WMS } \\
(\%)\end{array}$ & \begin{tabular}{c} 
Rank \\
\hline C
\end{tabular} & AESTHETIC VALUE \\
\hline 1. & Layout of Mobile application is good & $29(48.33)$ & $25(41.66)$ & $6(10.00)$ & 79.45 & I \\
\hline 2. & Content presentation style & $23(38.33)$ & $35(58.33)$ & $2(3.33)$ & 78.33 & II \\
\hline 3. & Gestural design of Mobile application & $24(40.00)$ & $32(53.33)$ & $4(6.66)$ & 77.78 & III \\
\hline 4. & $\begin{array}{l}\text { Visual appeal: How good does the Mobile } \\
\text { application look? }\end{array}$ & $20(33.33)$ & $35(58.34)$ & $5(8.33)$ & 75.00 & V \\
\hline 5. & Color scheme used in Mobile application & $25(41.67)$ & $29(48.33)$ & $6(10.00)$ & 77.22 & IV \\
\hline
\end{tabular}

Table.5 Respondents' perceived feedback on effectiveness about the Android Mobile Apps "Brucellosis Advisor Apps" (Information Component) ( $\mathrm{n}=60)$

\begin{tabular}{|c|c|c|c|c|c|c|}
\hline Sl. No. & Characteristics & $\begin{array}{l}\text { Highly } \\
\text { Satisfied }\end{array}$ & Satisfied & $\begin{array}{l}\text { Least } \\
\text { Satisfied }\end{array}$ & $\begin{array}{l}\text { WMS } \\
(\%)\end{array}$ & Rank \\
\hline $\mathrm{D}$ & INFORMATION & & & & & \\
\hline 1. & $\begin{array}{l}\text { Content available in each page of this Mobile } \\
\text { application is clearly visible }\end{array}$ & $19(31.67)$ & $39(65.00)$ & $2(3.33)$ & 76.11 & IV \\
\hline 2. & $\begin{array}{l}\text { Quantity of information provided on Mobile } \\
\text { application is sufficient }\end{array}$ & $23(38.33)$ & $34(56.67)$ & $3(5.00)$ & 77.78 & III \\
\hline 3. & Accuracy of Mobile application description & $13(21.67)$ & $45(75.00)$ & $2(3.33)$ & 72.78 & VI \\
\hline 4. & $\begin{array}{l}\text { Credibility of information provided in Mobile } \\
\text { application }\end{array}$ & $25(41.67)$ & $32(53.33)$ & $3(5.00)$ & 78.88 & II \\
\hline 5. & Quality of visual information of Mobile application & $21(35.00)$ & $34(56.67)$ & $5(8.83)$ & 75.56 & V \\
\hline 6. & $\begin{array}{l}\text { Accuracy and appropriateness of the health } \\
\text { information on Mobile application }\end{array}$ & $24(40.00)$ & $35(58.33)$ & $1(1.67)$ & 79.45 & I \\
\hline
\end{tabular}

(*Figures in parentheses indicate percentage)

Table.6 Respondents' perceived feedback on effectiveness about the Android Mobile Apps "Brucellosis Advisor Apps" (Subjective Quality Component) (n=60)

\begin{tabular}{|c|l|c|c|c|c|c|c|}
\hline S1. No. & \multicolumn{1}{|c|}{ Characteristics } & $\begin{array}{c}\text { Highly } \\
\text { Satisfied }\end{array}$ & Satisfied & $\begin{array}{c}\text { Least } \\
\text { Satisfied }\end{array}$ & $\begin{array}{c}\text { WMS } \\
(\%)\end{array}$ & Rank \\
\hline E & SUBJECTIVE QUALITY & & & & \\
\hline 1. & $\begin{array}{l}\text { Preciseness of content about Brucellosis in } \\
\text { application }\end{array}$ & $23(38.33)$ & $34(56.67)$ & $3(5.00)$ & 77.78 & II \\
\hline 2. & $\begin{array}{l}\text { Simplicity of content in enhancing knowledge } \\
\text { Worth recommending Mobile application to }\end{array}$ & $26(43.33)$ & $30(50.00)$ & $4(6.67)$ & 78.88 & I \\
\hline 3. & $\begin{array}{l}\text { Worth } \\
\text { other users }\end{array}$ & $33(55.00)$ & $6(10.00)$ & 75.00 & III \\
\hline 4. & $\begin{array}{l}\text { Text size of the words used in Mobile } \\
\text { application is appropriate }\end{array}$ & $16(26.67)$ & $40(66.67)$ & $4(6.67)$ & 73.33 & IV \\
\hline
\end{tabular}


Elizabeth et al., (2015) also revealed the adherent users' perceptions about app effectiveness that nearly half of respondents agree or strongly agree that health apps help them feel more healthy and full of energy.

\section{Respondents' perceived feedback on effectiveness about the Aesthetic Component of the Apps}

Talking about the aesthetic component of apps and its satisfaction level, it was found (Table 4), that respondents were satisfied in following components: Layout of Mobile application is good was given first rank, the probable reasons for this could be because respondents had android phones and application was specifically designed for smart phone. Content presentation style was given second rank; the probable reasons behind this could be the easy understanding and systematic presentation of information. While color scheme used in mobile application was ranked fifth.

\section{Respondents' perceived feedback on effectiveness about the Information Component of the Apps}

Talking about the information component and its satisfaction level, it was found (Table 5), that respondents were satisfied in following components: Accuracy and appropriateness of the health information on Mobile application was given first rank, this is due to the fact that respondents found information useful in prevention of brucellosis. Credibility of information provided in Mobile application was given second rank. The probable reasons behind this could be the knowledge of respondents about involvement of research scholar and scientist of ICAR-National Dairy Research Institute, Karnal in design of information. While quantity of information provided on Mobile application is sufficient and accuracy of Mobile application description were ranked third and six, respectively.

Respondents' perceived feedback on effectiveness about the Subjective Quality Component of the Apps

Coming to subjective Component of the Apps, it can be clearly seen (Table 6), that 'simplicity of content in enhancing knowledge' was ranked first while 'Preciseness of content about Brucellosis in application', 'Worth recommending Mobile application to other users', and 'text size of the words used in Mobile application is appropriate' were ranked second, third and fourth respectively.

From the study it was found that the respondents were highly satisfied in the following aspects of app components: "Engagement component" was ranked first in the satisfaction continuum; "functionality" and information component were ranked second and third, respectively. While "aesthetic value" and "subjective quality aspect" were ranked fourth and fifth in this regard respectively. Talking about the engagement component and its satisfaction level, it was found that respondents were satisfied in following components: "Meet the needs of target group" was given first rank, and "Create interest among users" was rank second in satisfaction continuum. Coming to functionality component, "Applicability of Mobile application in field condition" was ranked first while degree of easiness in obtaining desired information in simplest way was ranked third in satisfaction continuum. Applicability of Mobile application in field condition and accuracy, layout of Mobile application is good and appropriateness of the health information on Mobile application was ranked first in satisfaction continuum of functionality, aesthetic and subjective component of application. This result 
backings the fact that in this era of electronics communication, mobile apps can act as game changer to bridge the gap of information between dairy farmers and extension agencies.

\section{References}

Ajayi A.O., Alabi O.S. and Akinsola T.O. (2013). Knowledge and Perception of extension agents on information and communication technologies (ICTs) use in extension service delivery in Ondo State, Nigeria. African Journal of Agricultural Research, 8 (48): 62266233.

Chhachhar A.R., Querestic B., Khushk G.M. and Ahmed S. (2014).Impact of Information and Communication Technologies in Agriculture Development. J. Basic Appl. Sci. Res., 4(1): 281-288.

Elizabeth, L. M., David, H. and Gueorgi, K. (2015). Mobile Health Apps: Adoption, Adherence, and Abandonment. Ubicomp/ISWC '15 Adjunct, Osaka, Japan.

Monica, S., Randhawa, V. and Singh A.P. (2011). Designing, Validation and Evaluation of Self Instructional e-
Module on Photography for Online Learning. Indian Res. J. Ext. Edu., 11(1): 13-17.

Riley, W.T., Rivera, D.E., Atienza, A.A., Nilsen, W., Allison, S.M. and Mermelstein, R. (2011) Health behavior models in the age of mobile interventions: Are our theories up to the task? Trans. Behav. Med. 1(1): 53-71.

Salau, E. S. and Saingbe, N. D. (2008). Access and Utilization of information and communication technologies (ICTs) among agricultural research and extension workers in selected institutions in Nasarawa State, Nigeria. Journal of Production, Agriculture and Technology. 4 (2):1-11.

Shrija, S., Gopal, S. and Lal, S. P. (2018). Exploring the perception of the dairy farmers in relation to different components of the Android Mobile App 'Eco-Dairy'. International Journal of Agriculture Sciences, 10 (6): 56115613.

Stoyanov, S.R., Hides, L., Kavanagh, D.J., Zelenko, O., Tjondronegoro, D. and Mani, M. (2018). Mobile App Rating Scale: A New Tool for Assessing the Quality of Health Mobile Apps. JMIR Mhealth Uhealth, 3 (1): e27.

\section{How to cite this article:}

Verma, A.P., H.R. Meena, K.S. Kadian and Meena, B.S. 2019. Exploring the Perceived Feedback of Commercial Dairy Farmers about Effectiveness of Android Mobile Apps 'Brucellosis Advisor Apps'. Int.J.Curr.Microbiol.App.Sci. 8(01): 3007-3013. doi: https://doi.org/10.20546/ijcmas.2019.801.320 